TEME, г. XLIII, бр. 4, октобар - децембар 2019, стр. 957-980

Прегледни рад https://doi.org/10.22190/TEME191007057T

Примљено: 7. 10. 2019.

UDK 314.15:343.126.1

Ревидирана верзија: 14. 10. 2019.

Одобрено за штампу: 1. 12. 2019.

\title{
MIGRANTS IN DETENTION: THE APPROACH OF THE EUROPEAN COURT OF HUMAN RIGHTS
}

\author{
Veljko Turanjanin", Snežana Soković \\ University of Kragujevac, Faculty of Law, Kragujevac, Serbia \\ vturanjanin@jura.kg.ac.rs
}

\begin{abstract}
The Mediterranean migrant crisis is not calming down and in the last six decades the nature and character of these migrations has changed. The authors deal with one of the aspects of their position - detention. This work is divided into several parts. In the first part, the authors explore the problem of the migration crisis. After that, they explain in detail the Article 5 of the European Convention on Human Rights and Fundamental Freedoms. The main part of this work is devoted to the jurisprudence of the European Court of Human Rights related to the migrants' detention.
\end{abstract}

Key words: $\quad$ migrants, detention, adults, European Court of Human Rights,

European Convention on Human Rights and Fundamental Freedoms.

\section{ЛИШЕЊЕ СЛОБОДЕ МИГРАНАТА: ПРИСТУП ЕВРОПСКОГ СУДА ЗА ЉУДСКА ПРАВА}

\begin{abstract}
Апстракт
Аутори у раду разматрају питање положаја миграната према ставовима Европског суда за људска права. Узевши у обзир последњу деценију, могли бисмо рећи да је иста превасходно обележена таласима миграција са истока, које не јењавају, него се само трансформишу у зависности од отворених рута. Један од путева миграната ка Западној Европи представља Медитеран, а држава која је највише изложена овом таласу је Италија, при чему не заостају ни Грчка и Малта. Стога аутори у раду анализирају досадашње ставове Европског суда за људска права, у погледу лишавања слободе миграната, кроз многобројне пресуде у којима је овај суд дао смернице за однос према мигрантима.
\end{abstract}

Кључне речи: мигранти, лишење слободе, пунолетни мигранти, Европски суд за људска права, Европска конвенција за заштиту људских права и основних слобода. 


\section{INTRODUCTION}

The contemporary development of civilization is characterized by numerous legal issues. Some of them belong to the sphere of development or change of a country's legal system, such as discussions on euthanasia (Banović \& Turanjanin, 2014; Banović, Turanjanin, \& Miloradović, 2017; Banović, Turanjanin, \& Ćorović, 2018; Banović, Turanjanin, \& Ćorović, 2018; Turanjanin, Banović, \& Corović, 2018) or changes to the Criminal Code and the Criminal Procedure Code (Soković, Čvorović, \& Turanjanin, 2016; Soković, Turanjanin \& Čvorović, 2017; Soković, Turanjanin, \& Kolaković-Bojović, 2018; (Soković, Turanjanin, \& Čvorović, 2017), while others are imposed by changes in society, such as waves of migration. A key element of the EU's evolution is the abolition of internal borders and the establishment of the freedom of movement, which, however, is not accompanied by a single legal system (Mitsilegas, 2014, p. 182). The foundations of the modern system of migrant protection were laid after the Second World War (Betts, 2013, p. 10). The last decade, however, has been marked by two different approaches to the migrant issue, and on the one hand we have increased militarization and border control, with the raising of fence; and, on the other, the strengthening of human rights and freedoms of migrants (Aas and Gundhus, 2015, p. 1). The economic crisis and political change in certain regions of Africa and Asia inevitably cause challenges for Europe (Černič, 2016, p. 237) that are in this context primarily emigrational. International organizations around the world look at how human rights can protect migrants' rights (Cantor, 2014, p. 79), and the debate on the link between human rights and migrant rights is deeply relevant (Harvey, 2014, p. 44; McConnachie, 2017, p. 191). It is an important issue and a matter of the political discourse (Meçe, 2018, p. 45), and thereby, the biggest discussion on migrant control pertains to the legality of the activities of repression (pushbacks) (Markard, 2016, p. 591-592). Immigration control systems are today characterized by "extraterritoriality" strategies (Ryan, 2010, p. 3), which primarily include interception measures on ships at sea or in territorial waters of third countries and the appointment of immigration officers to prevent migrants from embarking on flights to a third country (Klug and Howe, 2010, p. 69-70). EU Member States use a range of means to control their borders, extending beyond their territories (Costello, 2012, p. 290). While, on the one hand, we have states' activities to address migrant issues, the problem has arisen pertaining to the extent to which the Convention is a means of extraterritorial immigration control, especially after the judgment of Banković and Others v. Belgium and Others further stirred the sea (Brouwer, 2010, p. 213). Both figuratively and literally.

The Mediterranean migrant crisis is not calming down. Between 1950 and 2010 however, the nature and character of these migrations changed (Haas, 2011, p. 60). Italy has, for many years, faced an influx of illegal migrants by sea, often organized by criminal groups (Pascale, 2010, 
p. 283). However, according to the proceedings pending and/or ended before the European Court of Human Rights ("the Court"), Greece and Malta do not lag behind Italy. With less success, migrants file complaints against other countries, such as countries in the region. Such voyages are fraught with life-threatening hazards, ships often carry far more migrants than a ship can dock, do not have standard equipment, and captains often are not professional sailors (Klug, 2014, p. 49). Migrants are in a difficult position in both developed and developing countries (Ogg, 2016, p. 385). It is a case of mixed migration, and while this concept is still evolving, it encompasses migrants of different nationalities, motives, etc. (Sharpe, 2018). However, the pressure of migration cannot relieve states of their human rights obligations (Moreno-Lax, 2012, p. 598). The focus of this paper is the Mediterranean crisis and the situation of migrants in detention, primarily from the perspective of the Court (Turanjanin, 2019a; Turanjanin, 2019b), with other countries, such as Australia, facing similar problems (Schloenhardt and Craig, 2015; Marmo and Giannacopoulos, 2017, p. 5; Henderson, 2014).

The 1951 Geneva Convention Relating to the Status of Refugees sets out situations in which a state must grant the refugee status to persons seeking that status. Article 1 of the Geneva Convention defines the concept of a refugee as a person who, due to a well-founded fear of persecution on the basis of race, religion, nationality, membership of a particular social group or political opinion, finds himself outside the country of his nationality and is unable or, because of such fear, does not want to use the protection of that country; or persons who, because they do not have a nationality but reside, because of such events, outside the country in which they were previously settled, and cannot or, because of such fear, do not wish to return to it. Thereafter, under Article 33, paragraph 1, no Contracting State shall in any way expel or return (refouler) ${ }^{1}$ a refugee to the border of a territory where his life or freedom would be threatened on the basis of race, religion, nationality, affiliation with a particular social group or political opinions. Of course, international law allows states to take reasonable measures in their territorial waters to prevent the entry of ships carrying illegal migrants (Guilfoyle, 2009 , p. 222). Simply, the link between migrants and migration control has always been a point of conflict between state sovereignty and international law (Gammeltoft-Hansen, 2011, p. 11), but also between law and politics. However, the existence of international treaties and national legislation guaranteeing rights does not mean that their violation will not occur at the same time (further on this topic: Storey, 2016, p. 20).

As we can see, one of the basic principles in this area is precisely the principle of non-refoulement, as pointed out by the UNHCR in its Note on

${ }^{1}$ This principle dates back to 1933 (Bhuiuon, 2013, p. 101). 
International Protection of 13 September 2001, emphasizing that it is a key principle of protection embodied in the Convention (see about the legal nature of this principle Greenman, 2015). In a significant sense, this principle is a logical continuation of the right to seek asylum, recognized in the Universal Declaration of Human Rights, which has come to be regarded as a rule of customary international law binding on all states. In addition, international humanitarian law establishes non-refoulement as a fundamental component of an absolute ban on torture and cruel, inhumane or degrading treatment or punishment. The duty not to return (refouler) has also been recognized as applicable to refugees regardless of the formal recognition of their status, so it obviously involves asylum seekers whose status has not yet been decided. It implies all measures attributable to the State that could have the effect of returning an asylum seeker or refugee to the borders of a territory where their life or liberty would be threatened, or where they would be at risk of persecution. These include border refusal, interception and indirect refoulement, either by an individual seeking asylum or in situations of mass influx. Although at first glance it may seem that returning a ship to the high seas does not have to lead to refoulement because the ship can theoretically sail to any country in the world that has sea access, the matter is far more complicated (Guilfoyle, 2009, p. 222). Resolution 1821 (2011) of the Parliamentary Assembly of the Council of Europe on the interception and rescue at sea of asylum seekers, refugees and irregular migrants is also very significant. Although individual states enter into treaties that somehow attempt to circumvent the rules of international law, they cannot be rendered invalid in this way. For example, Italy and Libya concluded several secret agreements in the period 2000-2012, some of which concerned the control of the smuggling of migrants to Italy and their sending back to Libya (Gallaghe and David, 2014, p. 7; Hessbruegge, 2012, p. 423; on smuggling and routes extensively in Tinti and Reitano, 2017), and Italy has concluded similar contracts with Tunisia. The treaties were repealed (Pera, 2017, p. 358) to conclude a new one two months after the verdict, which obliges Libya to strengthen its land and sea borders and Italy to provide technical assistance, equipment and training to Libyan officials (Gammeltoft-Hansen, 2014, p. 586). However, between May 6 and November 6, 2009, 834 persons were returned to Libya, 23 to Algeria (Giuffré, 2013, p. 697), and generally speaking, thousands of migrants were returned from European borders in recent years (Bevilacqua, 2017, p. 168).

\section{MIGRANT'S DETENTION UNDER THE CONVENTION}

Certain European countries have developed specific procedures for detaining asylum seekers until their issue is resolved (Costello i Mouzourakis, 2016, p. 60; Mainwaring \& Cook, 2018). Therefore, in migrant cases, it is not uncommon for a migrant to be detained illegally until his or 
her status and / or asylum claim is resolved. This is not a matter of classic detention in terms of criminal proceedings (Vrolijk, 2016, p. 48). However, if we reject the terminological differences, it is essentially a matter of detention, especially if the crime was committed at the same time. However, in the first place we have to explain, in short, the Article 5 of the Convention, particularly when it comes to the migrant cases. This paper focuses on the detention of adult migrants, since addressing the issue of minor accompanied and unaccompanied migrants would far exceed the limits of this paper.

\section{Right to liberty and security}

1. Everyone has the right to liberty and security of person. No one shall be deprived of his liberty save in the following cases and in accordance with a procedure prescribed by law:

(a) the lawful detention of a person after conviction by a competent court;

(b) the lawful arrest or detention of a person for noncompliance with the lawful order of a court or in order to secure the fulfillment of any obligation prescribed by law;

(c) the lawful arrest or detention of a person effected for the purpose of bringing him before the competent legal authority on reasonable suspicion of having committed an offence or when it is reasonably considered necessary to prevent his committing an offence or fleeing after having done so:

(d) the detention of a minor by lawful order for the purpose of educational supervision or his lawful detention for the purpose of bringing him before the competent legal authority;

(e) the lawful detention of persons for the prevention of the spreading of infectious diseases, of persons of unsound mind, alcoholics or drug addicts or vagrants;

(f) the lawful arrest or detention of a person to prevent his effecting an unauthorised entry into the country or of a person against whom action is being taken with a view to deportation or extradition.

2. Everyone who is arrested shall be informed promptly, in a language which he understands, of the reasons for his arrest and of any charge against him.

3. Everyone arrested or detained in accordance with the provisions of paragraph 1 (c) of this Article shall be brought promptly before a judge or other officer authorised by law to exercise judicial power and shall be entitled to trial within a reasonable time or to release pending trial. Release may be conditioned by guarantees to appear for trial. 
4. Everyone who is deprived of his liberty by arrest or detention shall be entitled to take proceedings by which the lawfulness of his detention shall be decided speedily by a court and his release ordered if the detention is not lawful.

5. Everyone who has been the victim of arrest or detention in contravention of the provisions of this Article shall have an enforceable right to compensation.

This Article concerns the protection of each person, as confirmed by the Court in Nada v. Switzerland (Nada v. Switzerland, 2012, § 224). Most EU countries allow migrants to be deprived of their liberty upon entering the country, most often by border police (Cornelisse, 2010, p. 8). Establishing a global image of imprisonment for migrants is considered extremely difficult (Fiske, 2016, p. 191). The grounds for deprivation of liberty are exhaustively stated in the Convention and a person cannot be deprived of his liberty beyond the enumerated grounds (see Saadi v. the United Kingdom, 2008, § 43). Article 5 enshrines a fundamental human right, namely the protection of the individual against arbitrary interference by the State with his or her right to liberty. Sub-paragraphs (a) to (f) of Article $5 \S 1$ contain an exhaustive list of permissible grounds on which persons may be deprived of their liberty and no deprivation of liberty will be lawful unless it falls within one of those grounds. Moreover, only a narrow interpretation of those exceptions is consistent with the aim of that provision, namely to ensure that no one is arbitrarily deprived of his or her liberty. One of the exceptions, contained in sub-paragraph (f) of Article $5 \S 1$, permits the State to control the liberty of aliens in an immigration context. This article does not require the detention to be reasonably considered necessary, for example to prevent the individual from committing an offence or fleeing. However, any deprivation of liberty under the second limb of Article $5 \S 1$ (f) will be justified only as long as deportation or extradition proceedings are in progress. If such proceedings are not prosecuted with "due diligence", the detention will cease to be permissible under Article $5 \S 1$ (f). The deprivation of liberty must also be "lawful". Where the "lawfulness" of detention is an issue, including the question of whether "a procedure prescribed by law" has been followed, the Convention refers essentially to national law and lays down the obligation to conform to the substantive and procedural rules of that law, but it requires in addition that any deprivation of liberty should be in keeping with the purpose of Article 5, namely to protect the individual from arbitrariness. In lying down that any deprivation of liberty must be effected "in accordance with a procedure prescribed by law", Article $5 \S 1$ primarily requires any arrest or detention to have a legal basis in domestic law, as the Court stressed in the Bozano v. France. 
However, the "lawfulness" of detention under domestic law is not always the decisive element, so the Court must moreover ascertain whether domestic law itself is in conformity with the Convention, including the general principles expressed or implied therein. In numerous judgments on this point, the Court stressed that, where deprivation of liberty is concerned, it is particularly important that the general principle of legal certainty be satisfied. It is therefore essential that the conditions for deprivation of liberty under domestic law be clearly defined and that the law itself be foreseeable in its application, so that it meets the standard of "lawfulness" set by the Convention, a standard which requires any law to be sufficiently precise to avoid all risk of arbitrariness (Nasrulloyev v. Russia, 2007, § 71; Khudoyorov v. Russia, 2005, § 125; Ječius v. Lithuania, 2000, § 56; Baranowski v. Poland, 2000, $\S 50-52$ ). In the migrant case Shamsa v. Poland, as well as in Steel and Others v. the United Kingdom, the Court stated that the standard of "lawfulness" established in the Convention requires that all law be sufficiently precise to allow the citizen - if need be, with appropriate advice - to foresee, to a degree that is reasonable in the circumstances, the consequences which a given action may entail (Shamsa v. Poland, 2003, § 40, Steel and Others v. the United Kingdom, 1998, § 54).

Further, words "in accordance with a procedure prescribed by law" do not merely refer back to domestic law. They also relate to the quality of the law, requiring it to be compatible with the rule of law, a concept inherent in all Articles of the Convention. The Court stresses that where deprivation of liberty is concerned it is particularly important that the general principle of legal certainty be satisfied. It is therefore essential that the conditions for deprivation of liberty under domestic law be clearly defined and that the law itself be foreseeable in its application, so that it meets the standard of "lawfulness" set by the Convention, a standard which requires that all law be sufficiently precise to allow the person - if need be, with appropriate advice to foresee, to a degree that is reasonable in the circumstances, the consequences which a given action may entail.

In addition, Article $5 \S 1$ requires that any deprivation of liberty should be in keeping with the purpose of protecting the individual from arbitrariness and the notion of "arbitrariness" in Article $5 \S 1$ extends beyond a lack of conformity with national law, so that deprivation of liberty may be lawful in terms of domestic law but still arbitrary, and therefore contrary to the Convention. The Court in Saadi v. the United Kingdom, A. and Others v. the United Kingdom and Rustamov v. Russia stated that to avoid being branded as arbitrary, detention under Article $5 \S 1$ (f) must be carried out in good faith; it must be closely connected to the grounds of detention relied on by the Government, the place and conditions of detention must be appropriate, and the length of the detention must not exceed that reasonably required for the purpose pursued (Saadi v. the United Kingdom, 2008, § 74, ECHR 2008; Rustamov v. Russia, 2012, § 150;; A. and Others v. the United Kingdom, 2009, § 164). 
As the Court stressed in a M.S.S. v. Belgium and Greece and Amuur v. France, the confinement of aliens, accompanied by suitable safeguards for the persons concerned, is acceptable only in order to enable States to prevent unlawful immigration while complying with their international obligations, in particular under the 1951 Geneva Convention relating to the Status of Refugees and the European Convention on Human Rights. States' legitimate concern to foil the increasingly frequent attempts to circumvent immigration restrictions must not deprive asylum-seekers of the protection afforded by these conventions (M.S.S. v. Belgium and Greece, 2011, § 216; Amuur v. France, 1996, § 43). In addition, where the Court is called upon to examine the conformity of the manner and method of the execution of the measure with the provisions of the Convention, it must look at the particular situations of the persons concerned (M.S.S. v. Belgium and Greece, 2011, § 217; Riad and Idiab v. Belgium, 2008, § 100).

In Medvedyev and Others v. France, in the first place, the applicants were placed under the control of the French Special Forces and imprisoned while navigating a ship supervised by the French forces, after which they were deprived of their liberty within the meaning of Article 5 of the Convention. The Court emphasized that it does not prevent States from cooperating in other forms of cooperation in the fight against illicit trafficking in narcotic drugs at sea. Diplomatic notes are a source of international law that can be compared to a treaty or agreement when there is a formal agreement between the competent authorities, a common position on a particular issue or even, for example, an expression of unilateral desire or commitment. The diplomatic statement in this case represents the Cambodian authorities' agreement to the Winner's interception. In the text of the diplomatic statement, "the ship is named the Winner, which flies the Cambodian flag", is stated as the sole object of the treaty, and the approval for interception, search and legal action in connection with the ship is confirmed. It is evident, however, that the treatment of crew members was not clearly defined in the statement and thus it was not established that the two states had agreed to deprive crew members of their liberty. Their compliance, however, could be interpreted as a "clearly defined law" within the meaning of case law. The diplomatic statement also did not satisfy the "foreseeability" condition. The state has not demonstrated the existence of co-operation and long-standing practices in the fight against drug trafficking at sea between Cambodia and France in relation to ships flying the Cambodian flag; on the contrary, Cambodia has not ratified the relevant conventions, and the use of an ad hoc diplomatic note, in the absence of any permanent bilateral or multilateral treaty or agreement concluded between the two countries, is a co-operation of exceptional and one-off nature that existed exclusively in this case. In terms of predictability, there should be no ambiguity for perpetrators charged with narcotics trafficking under the law under which legal action was taken against them. Otherwise, any act that is considered a criminal offense under domestic law would relieve the State of 
the obligation to pass the law of the required quality, especially with respect to Article 5 para. 1 Convention which would make sense of that provision (Medvedyev and Others v. France, 2010, §§ 93-103).

In Khlaifia and Others v. Italy, the applicants left Tunisia with others on board rudimentary vessels heading for the Italian coast. After several hours at sea, their vessels were intercepted by the Italian coastguard, which escorted them to a port on the island of Lampedusa. The applicants arrived on the island on 17 and 18 September 2011 respectively. The applicants were transferred to a Centro di Soccorso e Prima Accoglienza - "CSPA" on the island of Lampedusa at Contrada Imbriacola where, after giving them first aid, the authorities proceeded with their identification. They were accommodated in a part of the center reserved for adult Tunisians. According to the applicants, they were held in an overcrowded and dirty area and were obliged to sleep on the floor because of the shortage of available beds and the poor quality of the mattresses. They had to eat their meals outside, sitting on the ground. The center was kept permanently under police surveillance, making any contact with the outside world impossible. The applicants remained in the CSPA until 20 September, when a violent revolt broke out among the migrants. The premises were gutted by fire and the applicants were taken to a sports complex on Lampedusa for the night. At dawn on 21 September, they managed, together with other migrants, to evade the police surveillance and walk to the village of Lampedusa. From there, with about 1,800 other migrants, they started a demonstration through the streets of the island. After being stopped by the police, the applicants were taken first back to the reception center and then to Lampedusa airport. On the morning of 22 September 2011 the applicants were flown to Palermo. After disembarking, they were transferred to ships that were moored in the harbour there. The first applicant was placed on the Vincent, with some 190 other people, while the second and third applicants were put on board the Audace, with about 150 others. The applicants described the conditions as follows. All the migrants on each vessel were confined to the restaurant areas, access to the cabins being prohibited. They slept on the floor and had to wait several hours to use the toilets. They could go outside onto the decks twice a day for only a few minutes at a time. They were allegedly insulted and ill-treated by the police, who kept them under permanent surveillance, and they claimed not to have received any information from the authorities. The applicants remained on the ships for a few days. On 27 September 2011 the second and third applicants were taken to Palermo airport pending their removal to Tunisia; the first applicant followed suit on 29 September. Before boarding the planes, the migrants were received by the Tunisian Consul. In their submission, the Consul merely recorded their identities in accordance with the agreement between Italy and Tunisia of April 2011. In their application the applicants asserted that at no time during their stay in Italy had they been issued with any document. 
In this case, the Court had to firstly determine whether the applicants' deprivation of liberty was justified under one of the sub-paragraphs of Article $5 \S 1$ of the Convention, because any deprivation of liberty which does not fall within one of the sub-paragraphs of Article $5 \S 1$ of the Convention will inevitably breach that provision. The Court found that the provisions applying to the detention of irregular migrants were lacking in precision. That legislative ambiguity has given rise to numerous situations of de facto deprivation of liberty and the fact that placement in a CSPA is not subject to judicial supervision cannot, even in the context of a migration crisis, be compatible with the aim of Article 5 of the Convention: to ensure that no one should be deprived of his or her liberty in an arbitrary fashion. Firstly, Article 10 of Legislative Decree no. 286 of 1998 provides for the refusal of entry and removal of, among other categories of aliens, those allowed to remain temporarily in Italy on public assistance grounds, so, the Court has not found any reference therein to detention or other measures entailing deprivation of liberty that could be implemented in respect of the migrants concerned - this Article could have constituted the legal basis for the applicants' detention (Khlaifia and Others v. Italy, 2016, §§ 100-101). Secondly, the applicants were not only deprived of their liberty without a clear and accessible legal basis, they were also unable to enjoy the fundamental safeguards of habeas corpus, as laid down, for example, in Article 13 of the Italian Constitution (under that provision, any restriction of personal liberty has to be based on a reasoned decision of the judicial authority, and any provisional measures taken by a police authority, in exceptional cases of necessity and urgency, must be validated by the judicial authority within forty-eight hours). Accordingly, since the applicants' detention had not been validated by any decision, whether judicial or administrative, they were deprived of those important safeguards (Khlaifia and Others v. Italy, 2016, § 105).

In Annur v. France, the applicants arrived at Paris-Orly Airport on 9 March 1992 on board a Syrian Airlines flight from Damascus, where they had stayed for two months after travelling there via Kenya. They asserted that they had fled Somalia because, after the overthrow of the regime of President Siyad Barre, their lives were in danger and several members of their family had been murdered. Five of their cousins and thirteen other Somali nationals (including eleven children) arrived, some on the same flight and others from Cairo on 14 March. However, the airport and border police refused to admit them to French territory, on the ground that their passports had been falsified, and held them at the Hôtel Arcade, part of which had been let to the Ministry of the Interior and converted for use as a waiting area for Orly Airport. On 26 March the applicants applied to the urgent applications judge at the Créteil tribunal de grande instance at short notice seeking an order for their release from confinement at the Hôtel Arcade, which, they asserted, constituted a flagrantly unlawful act (voie de fait). France brought decisions to remove them from the French territory (Amuur v. France, 1996, §§ 7-14). In this 
case, France considered that the applicants' stay in the transit zone was not comparable to detention, while the Commission concluded that the applicants' stay in the international zone was no different from detention in the ordinary meaning of that term, but Article 5 cannot be applicable (Amuur v. France, 1996, §§ 38-40). However, the Court took a completely different position. According to it, in order to determine whether someone has been "deprived of his liberty", the starting-point must be his concrete situation, and account must be taken of a whole range of criteria such as the type, duration, effects and manner of implementation of the measure in question. The difference between deprivation of and restriction upon liberty is merely one of degree or intensity, and not one of nature or substance (Amuur v. France, 1996, § 42; Guzzardi v. Italy, 1980, § 92). The Court further emphasized:

Holding aliens in the international zone does indeed involve a restriction upon liberty, but one which is not in every respect comparable to that which obtains in centres for the detention of aliens pending deportation. Such confinement, accompanied by suitable safeguards for the persons concerned, is acceptable only in order to enable States to prevent unlawful immigration while complying with their international obligations, particularly under the 1951 Geneva Convention Relating to the Status of Refugees and the European Convention on Human Rights. States' legitimate concern to foil the increasingly frequent attempts to circumvent immigration restrictions must not deprive asylum-seekers of the protection afforded by these conventions. Such holding should not be prolonged excessively, otherwise there would be a risk of it turning a mere restriction on liberty - inevitable with a view to organising the practical details of the alien's repatriation or, where he has requested asylum, while his application for leave to enter the territory for that purpose is considered - into a deprivation of liberty. In that connection account should be taken of the fact that the measure is applicable not to those who have committed criminal offences but to aliens who, often fearing for their lives, have fled from their own country. Although by the force of circumstances the decision to order holding must necessarily be taken by the administrative or police authorities, its prolongation requires speedy review by the courts, the traditional guardians of personal liberties. Above all, such confinement must not deprive the asylum-seeker of the right to gain effective access to the procedure for determining refugee status (Amuur v. France, 1996, § 43).

The Court equalized the applicants' position with the deprivation of liberty in practice, in view of the restrictions suffered, with the remarks to the mere fact that it is possible for asylum-seekers to voluntarily leave the country where they wish to take refuge, but that it cannot exclude a restriction on liberty and furthermore, this possibility becomes theoretical if no other country offering protection comparable to the protection they expect to find in the country where they are seeking asylum is inclined or 
prepared to take them in. Sending the applicants back to Syria only became possible, apart from the practical problems of the journey, following negotiations between the French and Syrian authorities (Amuur v. France, 1996, § 48).

After the Amuur, the Court reached the judgment in Shamsa $v$. Poland. This case concerned the applicants, two brothers and Libyan nationals, who were arrested in Warsaw with no valid identity papers or residence permit. Their expulsion within 90 days was ordered and they were placed in detention pending expulsion. The authorities made three attempts to execute the expulsion order, but to no avail, partly because of the brothers' refusal to cooperate. Under Polish law an expulsion order must be enforced within 90 days, after which the person concerned must be released. The applicants' complained that they had been held by the Warsaw airport border police, with a view to their expulsion, in a transit zone after the date on which they should have been released under Polish law, namely on 25 August 1997. However, the authorities had continued to enforce the expulsion order, with no legal basis, after the statutory timelimit had expired and until 3 October 1997 when the applicants had been taken to hospital by the police for an examination and left. The Court pointed out that detention for a period of several days which has not been ordered by a court, a judge or any other person authorised by law to exercise judicial power cannot be considered "lawful" within the meaning of Article $5 \S 1$ of the Convention. Considering that the applicants' detention between 25 August and 3 October 1997 had not been "prescribed by law" or "lawful", the Court held that that there had been a violation of Article $5 \S 1$ of the Convention (Shamsa v. Poland, 2003).

In the next case, Riad and Idiab v. Belgium, the first applicant arrived in Belgium at Brussels National Airport on 27 December 2002, carrying a Lebanese travel document stating that he was a Palestinian refugee, but he was refused entry to Belgium as he did not have the necessary visas and he was taken to the Transit Centre on the premises of the Brussels National Airport. The second applicant arrived in Belgium at Brussels National Airport on a flight from Freetown on 24 December 2002. As he did not have a transit visa allowing him to travel onwards to London, steps were taken to refuse him entry to the Belgian territory and the carrier which had provided the flight was requested to take him, or have him taken, back to the country of origin or to another State where he could be allowed entry, so the second applicant was rerouted to Beirut, via Budapest. Nevertheless, when he underwent a check in the transit zone on the same date, this applicant stated that he did not wish to go to Beirut and requested recognition of his refugee status, maintaining that his life was in danger in Lebanon and he was issued with a document certifying that he had applied for asylum. He was taken to the same Transit Centre as the first applicant. 
Contrary to the Ammur case, the applicants in this case were confined in the transit zone not upon their arrival in the country but more than one month later, after decisions had been given ordering their release. Their confinement was ordered for an indefinite period and eventually lasted for fifteen days and eleven days respectively. To resolve this legal situation, the Court had to combine several principles from its earlier judgments. In the first place, the Court recalled the old rule from the Bozano v. France and Gebremedhin [Gaberamadhian] v. France, that it may happen that a Contracting State's agents conduct themselves unlawfully in good faith; in such cases, a subsequent finding by the courts that there has been a failure to comply with domestic law may not necessarily retrospectively affect the validity, under domestic law, of any implementing measures taken in the meantime. Matters would be different if the authorities at the outset knowingly contravened the legislation in force and, in particular, if their original decision was an abuse of power (Bozano v. France, 1986, § 55; Gebremedhin [Gaberamadhian] v. France, $2007, \S 56)$. So, the transfer to and confinement in the transit zone cannot therefore be regarded as the application in good faith of the immigration legislation. After that, the Court reiterates that according to its case-law, there must be some relationship between the ground of permitted deprivation of liberty relied on and the place and conditions of detention (Mubilanzila Mayeka and Kaniki Mitunga v. Belgium, 2006, § 53). The applicants were left to their own devices in the transit zone, without humanitarian or social support of any kind and the second applicant was placed in the transit zone, without any explanation of the existence, functioning and location of the centre, where he might have been given a more appropriate reception. The first applicant, who had initially been placed in the same situation, was given no information about the existence of the centre and was taken there only after he had described his situation to the officials at the border inspection post. According to the Court, such detention was not lawful (Riad and Idiab v. Belgium, 2008, §§ 76-79).

A very interesting case is also Nolan and K. v. Russia. Here, the applicant was a member of the Unification Church, a spiritual movement founded by Mr Sun Myung Moon in 1954. In 1994, the Church invited the applicant to assist its activities in Russia. The Ministry of Foreign Affairs of the Russian Federation granted the applicant the permission to stay in Russia. His permission to stay was subsequently renewed by the Ministry on a yearly basis through invitations issued by the registered religious organisation of the Unification Church in Moscow and an associated social organisation in St Petersburg, the Family Federation for World Peace and Unification. Further, on 12 July 2001 the applicant's son, K., was born. On 2 October 2001 the applicant and his wife separated; the applicant's wife returned to the United States and the applicant retained sole custody of the child. On 19 May 2002 the applicant travelled to Cyprus, and 2 June 2002 the applicant was in 
Moscow and on a flight from Cyprus. Nevertheless, upon his arrival at the transit hall, officials directed the applicant to wait in a small room adjacent to their office with a desk and a sofa, but no phone, ventilation or windows. Once he entered the room, the officials locked him in from outside. Initially, the applicant thought that this would be just for a few minutes, but after half an hour, he realised that he was being held in an improvised detention cell. He began knocking on the door, asking to be let out. The female officer responded through the door that he would not be let out until the morning, and told him to lie down and sleep. Ten minutes after that a male officer came with the applicant's visa stapled to a one-page document. He told the applicant that his visa had been cancelled and asked him to sign the document. The applicant did as he was requested, although he could not read the document, which was handwritten in Russian. The applicant indicated that his detention might have been effected in accordance with the Border Crossing Guidelines, since he fell in the category of persons whose entry into Russia was prohibited and he pointed out that the Border Crossing Guidelines had never been published or accessible to the public. Accordingly, the Court concluded that the Border Crossing Guideless did not meet the requirements of accessibility and foreseeability and fell short of the "quality of law" standard required under the Convention. Consequently, the Russian system failed to protect the applicant from arbitrary deprivation of liberty, and his detention cannot be considered "prescribed by law" for the purposes of Article $5 \S 1$ of the Convention (Nolan and K. v. Russia, 2009, § 99).

In Medvedyev and Others v. France, however, there exists no violation of paragraph 3 of Article 5. The fact is that the applicants were not brought before an investigating judge who could be considered a "judge or official of another judicially designated body" within the meaning of Article 5 para. 3 thirteen days after their detention. At the time of the interception, the Winner was on the high seas far from the French coast. There was nothing to indicate that the warship sailed longer than necessary to open the ship to France, especially given the weather conditions and poor condition of the Winner, so it was impossible to travel faster. In addition, the applicants claimed that they could have been brought before the authorities of a country closer to France, where they could have been brought immediately before the judicial authorities. As to the idea that they were able to cross the coast by a faster-moving French Navy, it is not for the Court to assess the justification of such work in the circumstances of the case. Finally, upon arriving in France, they spent only about eight or nine hours in detention before being brought before a judge. That period of eight or nine hours was entirely compatible with the concept of "brought promptly" contained in Article 5 para. 3. and in the Court's case-law (Medvedyev and others v.France, 2010, $\S \S 131-134)$. 
The applicant in S.K. v. Russia arrived in this state in October 2011. He was in possession of a visa declaring the purpose of his visit as business, which was due to expire in October 2012. However, the visa allowed the applicant to stay in Russia for no longer than ninety days in the course of a single visit and he was therefore expected to leave Russia in early 2012. The applicant did not leave and started to live together with Ms B. By judgment of 26 February 2015, the Sovetskiy District Court of Makhachkala found the applicant guilty of an offense and it sentenced him to a fine and a penalty of forcible administrative removal from Russia. However, the Court in this case did not engage too much into explaining the violation of the Article 5, finding a comparison in the previous judgments against Russia (Azimov. v. Russia, 2013; Kim v. Russia, 2014; L.M. and Others v. Russia, 2015; R. v. Russia, 2016). In the Court's view, it should have been sufficiently evident for the national authorities already that the applicant's removal was not practicable and would remain unlikely in view of the worsening conflict in Syria and in these circumstances, it was incumbent on the domestic authorities to consider alternative measures that could be taken in respect of the applicant. Nevertheless, once the order for the applicant's placement in a special detention facility for foreigners had been issued, the detention matter was not reassessed, in particular as to whether it would be practicable to ensure his removal to Syria (S.K. v. Russia, 2017, § 115).

Case J.R. and Others v. Greece concerned the conditions in which three Afghan nationals were held in the Vial reception centre, on the Greek island of Chios, and the circumstances of their detention. The applicants complained in particular about the length of their detention in the centre, which they regarded as arbitrary and that they had not received any information about the reasons for their detention, neither in their mother tongue nor in any other language. This is the first judgment where the Court held that there is no violation of Article $5 \S 1$. It found in particular that the applicants had been deprived of their liberty for their first month in the centre, until 21 April 2016 when it became a semi-open centre. The Court was nevertheless of the view that the one-month period of detention, whose aim had been to guarantee the possibility of removing the applicants under the EU-Turkey Declaration, was not arbitrary and could not be regarded as "unlawful" within the meaning of Article $5 \S 1$ (f) (J.R. and Others v. Greece, 2018).

In Amie and Others v. Bulgaria, the Court noted that the first applicant remained in detention pending the enforcement of the order for his expulsion for a total period of one year, eight months and twenty-four days: two months and twenty-two days in 2006, and one year, six months and two days in 2008-10. It appeared that the only steps taken by the authorities during that time were to write four times to the Lebanese Embassy in Sofia, asking it to issue a travel document for the applicant. Although apparently asked him to specify such, there is no indication that the authorities took any steps to 
themselves explore a country for the migrants. The enforcement of expulsion measures against refugees may involve considerable difficulty and even prove impossible because there is no readily available country to which they may be removed. However, if the authorities are aware of those difficulties, they should consider whether removal is a realistic prospect, and accordingly whether detention with a view of removal is from the outset, or continues to be, justified (Amie and Others v. Bulgaria, 2013, § 77). Such attitude is taken also in Ali v. Switzerland and A. and Others v. the United Kingdom (Ali v. Switzerland, 1997; A. and Others v. the United Kingdom, 2009, § 167).

Then, K.G. v. Belgium concerned an asylum-seeker who was placed and kept in detention under four decisions, for security reasons, while his asylum application was pending. In particular, the applicant was "placed at the Government's disposal" and held on that basis for approximately 13 months. The Court stated that there is no violation of Article $5 \S 1$ of the Convention. It specifically found that public interest considerations had weighed heavily in the decision to keep the applicant in detention, and saw no evidence of arbitrariness in the assessment made by the domestic authorities. In addition, it observed that the applicant's health had not been jeopardised and that he had benefited from special care in both of the centres where he had been detained. Lastly, the Court found that, in view of the issues at stake and the fact that the domestic authorities had acted with the requisite diligence, the length of time for which the applicant had been placed at the Government's disposal could not be regarded as excessive (K.G. v. Belgium, 2018).

In Abdolkhani and Karimnia v. Turkey, the Court found violation of Article $5 \S 1$, in which the applicants, Iranian nationals and former members of the People's Mojahedin Organisation in Iran, were being held in Gaziosmanpaşa Foreigners' Admission and Accommodation Centre in Kirklareli. The Court concluded that in the absence of clear legal provisions establishing the procedure for ordering and extending detention with a view of deportation and setting time-limits for such detention, the deprivation of liberty to which the applicants were subjected was not circumscribed by adequate safeguards against arbitrariness (Abdolkhani and Karimnia v. Turkey, 2009, § 135). The same approach was taken in a similar case, the Court stated in Ghorbanov and Others v. Turkey.

In a recent case before the Court, the applicant, an illegal migrant who entered the country with a fake passport, was detained for 18 months and 6 days, during which his asylum application was processed. However, according to the Court, the detention of a person is justified only while being handled at his request, but unless the due process has been conducted with due care, the detention ceases to be justified (as in Saadi v. Italy, 2008, § 72). Therefore, in the said case, the applicant's detention was unlawful (Haghilo v. Cyprus, 2019, § 207). 
In this moment, there are two applications referred to the Grand Chamber (Ilias and Ahmed v. Hungary, Z.A. and Others v. Russia), while in Kaak and Others v. Greece and A.E. and T.B. v. Italy applications communicated to the Greek Government on 07 September 2017 and to the Italian Government 24 November 2017 respectively). We will not comment on the Chamber's judgments before the final judgments of the Grand Chamber.

\section{Right to be Informed Promptly of the Reasons for Arrest}

Paragraph 2 of Article 5 lays down an elementary safeguard: any person who has been arrested should know why they are being deprived of their liberty. This provision is an integral part of the scheme of protection afforded by Article 5: any person who has been arrested must be told, in simple, non-technical language that they can understand, the essential legal and factual grounds for their deprivation of liberty, so as to be able to apply to a court to challenge its lawfulness. Whilst this information must be conveyed "promptly", it need not be related in its entirety by the arresting officer at the very moment of the arrest. Whether the content and promptness of the information conveyed is sufficient should be assessed in each case according to its special features. In addition, the Court has previously held that the requirement of prompt information is to be given an autonomous meaning extending beyond the realm of criminal law measures.

In Khlaifia and Others v. Italy the refusal-of-entry orders were apparently notified to the applicants very belatedly, on 27 and 29 September 2011, respectively, although they had been placed in the CSPA on 17 and 18 September and consequently, even if the orders had contained information as to the legal basis for the detention, which was not the case, they would not in any event have satisfied the requirement of promptness, so there has been a violation of Article $5 \S 2$ of the Convention (Khlaifia and Others v. Italy, 2016, § 120). Further, the Court in J.R. and Others v. Greece held that there had been a violation of Article $5 \S 2$, finding that the applicants had not been appropriately informed about the reasons for their arrest or the remedies available in order to challenge that detention (J.R. and Others v. Greece, 2018).

In the specific case of Abdolkhani and Karimnia v. Turkey, there exists a violation of the Article $5 \S 2$ because of the absence of a reply from the Government and any document in the case file to show that the applicants were informed of the grounds for their continued detention, subsequently leading the Court to the conclusion that the reasons for the applicants' detention were never communicated to them by the national authorities (Abdolkhani and Karimnia v. Turkey, 2009, § 138). 
Right to Have Lawfulness of Detention Decided Speedily by a Court

Article $5 \S 4$ entitles detained persons to institute proceedings for a review of compliance with the procedural and substantive conditions which are essential for the "lawfulness", in Convention terms, of their deprivation of liberty. The notion of "lawfulness" under paragraph 4 has the same meaning as in Paragraph 1, such that a detained person is entitled to a review of the "lawfulness" of their detention in the light not only of the requirements of domestic law but also of the Convention, the general principles embodied therein and the aim of the restrictions permitted by Article $5 \S 1$. Article $5 \S 4$ does not guarantee a right to judicial review of such a scope as to empower the court, on all aspects of the case including questions of pure expediency, to substitute its own discretion for that of the decision-making authority. The review should, however, be wide enough to bear on those conditions which are essential for the "lawful" detention of a person according to Article $5 \S 1$. The reviewing "court" must not have merely advisory functions but must have the competence to "decide" the "lawfulness" of the detention and to order release if the detention is unlawful. The existence of the remedy must nevertheless be sufficiently certain, not only in theory but also in practice, for its failing would represent the lack of the requisite accessibility and effectiveness. Article $5 \S 4$ also secures the right to have the lawfulness of their detention decided "speedily" by a court and to have their release ordered if the detention is not lawful, both to persons arrested or detained. Proceedings concerning issues of deprivation of liberty require particular expedition, and any exceptions to the requirement of "speedy" review of the lawfulness of a measure of detention call for strict interpretation. The question of whether the principle of speedy proceedings has been observed is not to be addressed in the abstract but in the context of a general assessment of the information, taking into account the circumstances of the case, particularly in the light of the complexity of the case, any specificities of the domestic procedure and the applicant's behaviour in the course of the proceedings. In principle, however, since the liberty of the individual is at stake, the State must ensure that the proceedings are conducted as quickly as possible.

In Khlaifia and Others v. Italy, the Court stated that the Italian legal system did not provide the applicants with a remedy whereby they could obtain a judicial decision on the lawfulness of their deprivation of liberty and makes it unnecessary for the Court to determine whether the remedies available under Italian law could have afforded the applicants sufficient guarantees for the purposes of Article $5 \S 4$ of the Convention. In addition, the Court emphasized that the refusal-of-entry orders cannot be regarded as the decisions on which the applicants' detention was based, and the lodging of an appeal against them could not, in any event, have taken place until after the applicants' release on their return to Tunisia (Khlaifia and Others v. Italy, 2016, § 134). Accordingly, there has thus been a violation of 
Article $5 \S 4$ of the Convention. A violation of Article $5 \S 4$ exists also in the Abdolkhani and Karimnia v. Turkey, because the Turkish legal system did not provide the applicants with a remedy whereby they could obtain judicial review of the lawfulness of their detention (Abdolkhani and Karimnia v. Turkey, 2009, § 142).

\section{CONCLUSION}

The second half of the XX and the beginning of the XXI century was marked by waves of migration which move from east to west, from poorer to richer states. Migration flows are different and routes vary depending on the attitude of individual countries towards migrants. As is well known, Serbia is not spared from migration, although they certainly do not belong to countries that represent the final destination for migrants, but only a transition country. There are exceptions, of course. On the one hand, Italy is the most exposed to the wave of migration coming from the sea, most often from Libya and Tunisia. An attempt by the Italian authorities to stop the migration by contracting with the countries concerned has failed. The applications submitted to the Court against Italy were successful, and from the migrants' points of view, which the Court acknowledged, violations of the Convention's rights were present. Greece and Malta, on the other hand, are also countries that are affected by migration, and judging by the Court's judgments, these countries have hitherto suffered the most serious violations of Convention rights for unaccompanied and accompanied migrant children. This paper focuses on the detention of adult migrants, since addressing the issue of minor accompanied and unaccompanied migrants would far exceed the limits of this paper. As we have noticed in the analysis of the judgments given, violations of the rights guaranteed by the Convention are, unfortunately, not rare. Despite the fact that it is not easy for any European country exposed to the migration wave to cope with the problem, it does not justify drastic human rights violations in this area. Whether the situation will improve in the coming period remains to be seen.

\section{REFERENCES}

Abdolkhani and Karimnia v. Turkey, Application no. 30471/08 (ECtHR September 22, 2009).

A. and Others v. the United Kingdom, Application no. 3455/05 (ECtHR February 19, 2009).

A.E. and T.B. v. Italy, Applications nos. 18911/17, 18941/17 and 18959/17 (ECtHR).

Aas, K. F., \& Gundhus, H. O. (2015). Policing Humanitarian Borderlands: Frontex, Human Rights and the Precariousness of Life. Brit. J. Criminol. vol. 55, 1-18.

Ali v. Switzerland, Application no. 24881/94 (Commission's report February 26, 1997).

Amie and Others v. Bulgaria, Application no. 58149/08 (ECtHR February 12, 2013).

Amuur v. France, Application no. 19776/92 (ECtHR June 25, 1996).

Azimov. v. Russia, Application no. 67474/11 (ECtHR April 18, 2013). 
Banković and Others v. Belgium and Others, Application no. 52207/99 (ECtHR December 12, 2001).

Banović, B., \& Turanjanin, V. (2014). Euthanasia: Murder or Not; A Comparative Approach. Iranian Journal of Public Health, vol. 43, no. 10, 1316-1323.

Banović, B., Turanjanin, V., \& Ćorović, E. (2018). Physician-assisted Suicide in Serbia. Iranian Journal of Public Health, vol. 47, no. 4, 538-545.

Banović, B., Turanjanin, V., \& Ćorović, E. (2018). Pravo na dostojanstvenu smrt [Right to Dignified Death in Serbia]. Srpska Politička Misao, no. 2, 273-287.

Banović, B., Turanjanin, V., \& Miloradović, A. (2017). An Ethical Review of Euthanasia and Physician-assisted Suicide. Iranian Journal of Public Health, vol. 46, no. 2, 173-179.

Baranowski v. Poland, Application no. 28358/95 (ECtHR March 28, 2000).

Betts, A. (2013). Survival Migration: Failed Governance and the Crisis of Displacement. Ithaca-London: Cornell University Press.

Bevilacqua, G. (2017). Exploring the Ambiguity of Operation Sophia Between Military and Search and Rescue Activities. In G. Andreone, The Future of the Law of the Sea: Bridging Gaps Between National, Individual and Common Interests (pp. 165189). Rome: Springer.

Bhuiuon, J. H. (2013). Protection of Refugees throgh the Principle of Non-Refoulement. In R. Islam, \& J. H. Bhuiyan, An Introduction to International Refugee Law (pp. 99132). Leiden-Boston: Martinus Nijhoff Publishers.

Bozano v. France, Application no. 9990/82 (ECtHR December 18, 1986).

Brouwer, E. (2010). Extraterritorial Migration Control and Human Rights: Preserving the Responsibility of the EU and its Member States. In B. Ryan, \& V. Mitsilegas, Extraterritorial Immigration Control: Legal Challenges (pp. 199-228). LeidenBoston: Martinus Nijhoff Publishers.

Cantor, D. J. (2014). Reframing Relationships: Revisiting the Procedural Standards for Refugee Status Determination in Light of Recent Human Rights Treaty Body Jurisprudence. Refugee Survey Quarterly, vol 34, 79-106.

Černič, J. L. (2016). The European Court of Human Rights, Rule of Law and SocioEconomic Rights in Times of Crises. Hague J Rule Law, vol. 8, 227-247.

Cornelisse, G. (2010). Immigration Detention and Human Rights Rethinking Territorial Sovereignty. Leiden-Boston: Martinus Nijhoff Publishers.

Costello, C. (2012). Courting Access toAsylum in Europe: Recent Supranational Jurisprudence Explored. Human Rights Law Review, vol. 12, no. 2, 287-339.

Costello, C., \& Mouzourakis, M. (2016). EU Law and the Detainability of AsylumSeekers. Refugee Survey Quarterly, vol. 35, 47-73.

Fiske, L. (2016). Human Rights, Refugee Protest and Immigration Detention. London: Palgrave Macmillan.

Gallaghe, A. T., \& David, F. (2014). The international law of migrant smuggling. Cambridge: Cambridge University Press.

Gammeltoft-Hansen, T. (2011). Access to Asilum: International Refugee Law and the Globalization of Migration Control. Cambridge: Cambridge University Press.

Gammeltoft-Hansen, T. (2014). International Refugee Law and Refugee Policy: The Case of Deterrence Policies. Journal of Refugee Studies, Vol. 27, No. 4, 574-595.

Gebremedhin [Gaberamadhian] v. France, Application no. 25389/05 (ECtHR April 26, 2007).

Ghorbanov and Others v. Turkey, Application no. 28127/09 (ECtHR December 03, 2013).

Giuffré, M. (2013). State Responsibility Beyond Borders: What Legal Basis for Italy's Push-backs to Libya? International Journal of Refugee Law, Vol. 24, No. 4, 692-734. 
Greenman, K. (2015). A Castle Built on Sand? Article 3 ECHR and the Source of Risk in Non-Refoulement Obligations in International Law. International Journal of Refugee Law, Vol. 27, No. 2, 264-296.

Guilfoyle, D. (2009). Shipping Interdiction and the Law of the Sea. Cambridge: Cambridge University press.

Guzzardi v. Italy, Application no. 7367/76 (ECtHR November 6, 1980).

Haas, H. (2011). Mediterranean migration futures: Patterns, drivers and scenarios. Global Environmental Change, 59-69.

Haghilo v. Cyprus, Application no. 47920/12 (ECtHR March 26, 2019).

Harvey, C. (2014). Time for Reform? Refugees, Asylum-seekers, and Protection Under International Human Rights Law. Refugee Survey Quarterly, vol 34, 43-60.

Henderson, C. (2014). Australia's Treatment of Asylum Seekers: From Human RightsViolations to Crimes Against Humanity. Journal of International Criminal Justice, vol. 12, 1161-1181.

Hessbruegge, J. (2012). Introductory note to the European Court of Human Rights: Hirsi Jamaa et al. v. Italy. International Legal Materials, vol. 51, 423-476.

Ilias and Ahmed v. Hungary, Application no. 47287/15 (ECtHR March 14, 2017).

J.R. and Others v. Greece, Application no. 22696/16 (ECtHR January 25, 2018).

Ječius v. Lithuania, Application no. 34578/97 (ECtHR July 31, 2000).

K.G. v. Belgium, Application no. 52548/15 (ECtHR November 06, 2018).

Kaak and Others v. Greece, Application no. 34215/16 (ECtHR).

Khlaifia and Others v. Italy, Application no. 16483/12 (ECtHR December 15, 2016).

Khudoyorov v. Russia, Application no. 6847/02 (ECtHR November 08, 2005).

Kim v. Russia, Application no. 44260/13 (ECtHR July 17, 2014).

Klug, A. (2014). Strengthening the Protection of Migrants and Refugees in Distress at Sea through International Cooperation and Burden-Sharing. International Journal of Refugee Law, 2014, Vol. 26, No. 1, 48-64.

Klug, A., \& Howe, T. (2010). The Concept of State Jurisdiction and the Applicability of the Non-refoulement Principle to Extraterritorial Interception Measures. In B. Ryan, \& V. Mitsilegas, Extraterritorial Immigration Control: Legal Challenges (pp. 69-102). Leiden-Boston: Martinus Nijhoff Publishers.

L.M. and Others v. Russia, Application nos. 40081/14, 40088/14 and 40127/14 (ECtHR October 15, 2015).

M.S.S. v. Belgium and Greece, Application no. 30696/09 (ECtHR January 21, 2011).

Mainwaring, C., \& Cook, M. L. (2018). Immigration detention: An Anglo model. Migration Studies, 1-22.

Markard, N. (2016). The Right to Leave by Sea: Legal Limits on EU Migration Control by Third Countries. The European Journal of International Law Vol. 27 no. 3, 591-616.

Marmo, M., \& Giannacopoulos, M. (2017). Cycles of judicial and executive power in irregular migration. Comparative Migration Studies, vol. 5, 1-18.

McConnachie, K. (2017). Refugee Protection and the Art of the Deal. Journal of Human Rights Practice, vol. 9, 190-196.

Meçe, M. H. (2018). Risk Factors of the Irregular Migratory Waves on the Western Balkan Route: Implications in the European Union Countries. In E. Balica, \& V. Marinescu, Migration and Crime: Realities and Media Representations (pp. 4568). Bucharest: Palgrave Macmillan.

Medvedyev and Others v. France, Application no. 3394/03 (ECtHR March 29, 2010).

Mitsilegas, V. (2014). Solidarity and Trust in the Common European Asylum System. Comparative Migration Studies, vol. 2, no. 2, 181-202. 
Moreno-Lax, V. (2012). HirsiJamaa and Others v Italy or the Strasbourg Court versus Extraterritorial Migration Control? Human Rights Law Review, vol. 12, no. 3 , 574-598.

Mubilanzila Mayeka and Kaniki Mitunga v. Belgium, Application no. 13178/03 (ECtHR October 12, 2006).

Nada protiv Švajcarske, Predstvka broj 10593/08 (ESLJP septembar 12, 2012).

Nasrulloyev v. Russia, Application no. 656/06 (ECtHR October 01, 2007).

Nolan and K. v. Russia, Application no. 2512/04 (ECtHR February 12, 2009).

Ogg, K. (2016). Protection from 'Refuge': On What Legal Grounds Will a Refugee Be Saved from Camp Life? International Journal of Refugee Law, Vol. 28, No. 3, 384-415.

Pascale, A. (2010). Migration Control at Sea: The Italian Case. In \&. V. B. Ryan, Extraterritorial Immigration Control: Legal Challenges (pp. 281-310). Leiden-Boston: Martinus Nijhoff Publishers.

Pera, A. (2017). The residence permit for third-country nationals who are victims of human traffiking: A double-face instrument between compliance strategy and protection of human rights. Journal of Financial Crime, Vol. 24 No. 2, 347-361.

R. v. Russia, Application no. 11916/15 (ECtHR January 26, 2016).

Riad and Idiab v. Belgium, Applications nos. 29787/03 and 29810/03 (ECtHR January 24, 2008).

Rustamov v. Russia, Application no. 11209/10 (ECtHR July 03, 2012).

Ryan, B. (2010). Extraterritorial Immigration Control: What Role for Legal Guarantees? In B. Ryan, \& V. Mitsilegas, Extraterritorial Immigration Control: Legal Challenges (pp. 3-38). Leiden-Boston: Martinus Nijhoff Publishers.

S.K. v. Russia, Application no. 52722/15 (ECtHR February 14, 2017).

Saadi v. Italy, Application no. 37201/06 (ECtHR February 28, 2008).

Saadi v. the United Kingdom, Application no. 13229/03 (ECtHR January 28, 2008).

Schloenhardt, A., \& Craig, C. (2015). 'Turning Back the Boats': Australia's Interdiction of Irregular Migrants at Sea. International Journal of Refugee Law, Vol. 27, No. 4, 536-572.

Shamsa v. Poland, Application nos. 45355/99 and 45357/99 (ECtHR November 27, 2003).

Sharpe, M. (2018). Mixed Up: International Law and the Meaning(s) of "Mixed Migration". Refugee Survey Quarterly, vol. 37, 116-138.

Soković, S., Čvorović, D., \& Turanjanin, V. (2016). Cooperation between the Public Prosecutor and the Police in Serbia. Zbornik radova Pravnog fakulteta u Novom Sadu, no. 3, 843-860.

Soković, S., Turanjanin, V., \& Čvorović, D. (2017). Cooperation between Police and Public Prosecutor - Law and Practice in Serbia. Zbornik radova Pravnog fakulteta u Novom Sadu, no. 2, 337-352.

Soković, S., Turanjanin, V., \& Čvorović, D. (2017). Main Hearing to the New Serbian Criminal Procedure CodeČ Survez in Practice. Zbornik radova Pravnog fakulteta u Nišu, no. 75, 145-159.

Soković, S., Turanjanin, V., \& Kolaković-Bojović, M. (2018). The Role of Defence Counsel in the Serbian Criminal Procedure Code: the Norm and Practice . Anali Pravnog fakulteta u Zenici, 41-58.

Steel and Others v. The United Kingdom, Application no. 24838/94 (ECtHR September 23, 1998).

Storey, H. (2016). The Meaning of "Protection" within the Refugee Definition. Refugee Survey Quarterly, vol 35, 1-34.

Tinti, P., \& Reitano, T. (2017). Migrant, Refugee, Smuggler, Savior. Oxford: Oxford University Press. 
Turanjanin, V., Banović, B., \& Ćorović, E. (2018). Euthanasia and Physician-assisted Suicide in South-East Europe. Beau Bassin: LAP.

Turanjanin, V. (2019a). Лишење слободе малолетних миграната са и без пратње према ставовима Европског суда за људска права [Unaccompanied migrant minors detention before the European Court of Human Rights]. Glasnik prava, no. 2, 17-36

Turanjanin, V. (2019b). Unaccompanied migrant minors detention before the European Convention on Human Rights and Fundamental Freedoms. In Z. Pavlović and I. Stevanović, Yearbook - Human Rights Protection - Protection of the Rights of the Child (pp. 379-397). Novi Sad: Ombudsman.

Vrolijk, M. A. (2016). Immigration Detention and Non-removability Before the European Court of Human Rights. In M. J. Guia, R. Koulish, \& V. Mitsilegas, Immigration Detention, Risk and Human Rights: Studies on Immigration and Crime (pp. 4772). Heidelberg-New York-Dordrecht-London: Springer.

Z.A. and Others v. Russia, Applications nos. 61411/15, 61420/15, 61427/15 and 3028/16 (ECtHR March 28, 2017).

\title{
ЛИШЕЊЕ СЛОБОДЕ МИГРАНАТА: ПРИСТУП ЕВРОПСКОГ СУДА ЗА ЉУДСКА ПРАВА
}

\author{
Вељко Турањанин ${ }^{1}$, Снежана Соковић ${ }^{2}$ \\ Универзитета у Крагујевцу, Правни факултет, Крагујевац, Србија
}

\section{Резиме}

Иако је крај 2019. године, мигрантска криза проналази начине да се продуби, а пред Европским судом за људска права јављају се нови проблеми у тумачењу кршења и очувања људских права. Пре свега неколико месеци, тачније, дана 25. јуна 2019. године, Европски суд за људска права одбио је захтев подносилаца у предмету Rackete и други против Италије, који су, у складу са чланом 39 Rules of Court тражили дозволу за искрцавање на обали Италије са брода Sea-Watch 3. У конкретном предмету подносиоци представке су капетаница брода и око четрдесет лица који су држављани Нигерије, Гвинеје, Камеруна, Малија, Обале слоноваче, Гане, Буркине Фасо и Гвинеје, који су се од 12. јуна 2019. године налазили на броду, у време писања представке ван територијалних вода Италије. Потом, дана 15. јуна је десет особа добило дозволу да се искрца са брода, и то три породице, малолетно дете и жена у другом стању, а на основу здравствених разлога у ноћи између 21. и 22. јуна још једно лице је искрцано на обалу Италије. У међувремену, дана 17. јуна, брод је затражио од регионалног управног суда да по хитном поступку суспендује забрану броду да уђе у територијалне воде Италије. Два дана касније захтев је одбијен с образложењем да, поред лица која су добила одобрење за искрцавање, остала лица не потпадају под категорију осетљивих лица, те да према томе не постоје изузетно озбиљни и хитни разлози за примену хитних мера. Након тога, подносиоци су од Суда затражили дозволу да се искрцају како би затражили међународну заштиту или да буду одведени на сигурно место. Међутим, Суд је одбио да изда привремену меру (које се иначе издају само у ситуацији када је подносилац суочен са стварним ризиком наношења непоправљиве штете), ослањајући се на италијанске власти да ће наставити да пружају сву потребну помоћ лицима која се налазе на броду и која су посебно рањива због година живота или 
здравственог стања. Капетаница брода је пак, не могавши више да чува мигранте на броду због све веће суицидалне претње, пробила блокаду заобишавши брод који је блокирао пут и наневши му малу штету. Искрцала је преостале мигранте, те је ухапшена, а након пуштања на слободу налази се на скривеној локацији у Алпима. И тако, с једне стране, имамо мноштво проблема с којима се суочавају како државе тако и мигранти, а долази до различитих форми лишења слободе, са друге стране. Суд је у многобројним пресудама покушао да јасно разграничи оправдано лишење слободе од неоправданог. Кључни члан Конвенције у овој области је члан 5, при чему смо због обима рада заобишли проблематику члана 3 Конвенције, те проблеме с којима се суочавају малолетни мигранти са пратњом и без пратње. 